\title{
PENGARUH PROFITABILITAS, PERTUMBUHAN AKTIVA, DAN STRUKTUR AKTIVA TERHADAP KEPUTUSAN PENDANAAN PADA BANK PERMATA CABANG PADANG
}

\author{
Mega Oksha Wijaya, Muhammad Rivandi \\ Sekolah tinggi ilmu ekonomi KBP \\ Email: okshamega@gmail.com \\ Muhammadrivandi@akbpstie.ac.id
}

\begin{abstract}
Abstrak
Keputusan pendanaan adalah bagian dari keputusan keuangan yang berkaitan dengan sumber dana dalam perusahaan. Penelitian ini bertujuan untuk mengetahui pengaruh profitabilitas, pertumbuhan aktiva dan struktur aktiva terhadap keputusan pendanaan.sampel yang digunakan adalah laporan keuangan pada Bank permata sebanyak 33 data. Pengujian hipotesis dalam penelitian ini menggunakan regresi linier berganda. Hasil penelitian menunjukkan secara parsial variabel profitabilitas dan pertumbuhan asset tidak berpengaruh signifikan terhadap keputusan pendanaan dan hanya variabel struktur aktiva yang berpengaruh Negatif signifikan terhadap keputusan pendanaan.
\end{abstract}

kata kunci: keputusan pendanaan, profitabilitas, pertumbuhan aktiva, struktur aktiva

\section{Abstract}

Funding decisions are part of financial decisions related to funding sources within the company. This study aims to determine the effect of profitability, growth of assets and asset structure on funding decisions. The sample used is 33 financial statements on Permata Banks. Testing the hypothesis in this study using multiple linear regression. The results showed partially the variables of profitability and asset growth did not have a significant effect on funding decisions and only asset structure variables that have significant negative influence on funding decisions.

Keywords: funding decisions, profitability, asset growth, asset structure

\section{PENDAHULUAN}

Keputusan pendanaan berhubungan dengan alternatif pendanaan yang dilakukan oleh perusahaan. Sudana (2011) menyatakan bahwa, "keputusan pendanaan berkaitan dengan proses pemilihan sumber dana yang dipakai untuk membelanjai investasi yang direncanakan dengan berbagai alternatif sumber dana yang tersedia, sehingga diperoleh suatu kombinasi pembelanjaan yang paling efektif'. Alternatif pendanaan yang dilakukan oleh perusahaan dapat berasal dari beberapa sumber, seperti yang dijelaskan oleh Keown \& Martin (2011) "pembiayaan datang dari dua sumber utama : hutang (kewajiban-kewajiban) dan ekuitas. Hutang adalah uang yang telah dipinjam dan harus dibayar kembali pada tanggal yang telah ditentukan. Ekuitas, disisi lain, menunjukkan investasi pemegang saham dalam perusahaan".

Keputusan pendanaan terdiri dari struktur modal dan struktur hutang. Faktor yang mempengaruhi struktur modal didalam keputusan pendanaan adalah 1) Tingkat penjualan, perusahaan dengan penjualan yang relatif stabil dapat menggunakan hutang lebih besar dari pada perusahaan dengan penjualan yang tidak stabil. 2) Struktur aset, perusahaan dengan 
struktur aset yang fleksibel cendrung menggunakan leverage lebih besar dari pada perusahaan yang struktur asetnya tidak fleksibel. 3) Tingkat pertumbuhan perusahaan, apabila faktor lain sama maka perusahaan yang memiliki tingkat pertumbuhan tinggi cendrung akan menggunakan sumber dari luar.

Keputusan pendanaan didefinisikan sebagai keputusan yang menyangkut komposisi pendanaan yang dipilih oleh perusahaan (Hasnawati, 2005). Pada prinsipnnya, setiap perusahaan membutuhkan dana untuk pengembangan bisnisnya. Langkah yang dilakukan dalam memenuhi kebutuhan dana, perusahaan harus mempertimbangkan dan menganalisis berbagai alternatif sumber-sumber pendanaan yang berpotensi dan efisien di manfaatkan oleh perusahaan.

Menurut Sartono (2001) profitabilitas adalah kemampuan perusahaan memperoleh laba dalam hubungan dengan penjualan,total aktiva ataupun modal sendiri. Suatu ukuran dalam presentase yang digunakan untuk menilai sejauh mana perusahaan mampu menghasilkan laba pada tingkat yang dapat diterima. Rasio utama dalam seluruh laporan keuangan,karena tujuan utama perusahaan adalah hasil koperasi dan keungtungan.

Profitabilitas suatu perusahaan merupakan perbandingan antara laba dengan aktiva dan modal yang menghasilkan laba tersebut. Jika perusahaan meningkatkan porsi hutang ,maka perusahaan itu secara otomatis akan meningkatkan risiko keuangannya. Namun jika perusahaan menggunakan modal sendiri. Perusahaan juga harus mempertimbangkan pajak yang harus ditanggung. Kemampuan perusahaan dalam memperoleh laba selama periode tertentu dan juga memberikan gambaran tentang tingkat efektifitas manajemen dalam melaksanakan kegiatan operasinya (Mulyadi, 2002). Jika laba yang dihasilkan perusahaan lebih tinggi maka memungkinkan perusahaan-perusahaan tersebut menggunakan sebagian besar pendanaannya dari sumber internal perusahaan (Brigham \& Gepenski 2008). Profitabilitas yang merupakan elemen penting untuk menilai keberhasilan manajemen didalam mengelola kinerja keuangan perusahaan yang fundamental. Profitabilitas secara teori menunjukan kemampuan manajemen didalam menghasilkan laba dengan memanfaatkan berbagai sumber keuangan didalam perusahaan (Rivandi, Saleh, \& Septiano, 2017).

Menurut Mulviawan (2011), Ayulestari et al., (2012) menyatakan bahwa profitabilitas berpengaruh positif terhadap keputusaan pendanaan. Profitabilitas akan menjadi pertimbangan apakah perusahaan akan menggunakan dana eksternal atau tidak, ini sesuai dengan pecking order theory yang menyatakan jika perusahaan memiliki dana internal yang memadai maka perusahaan akan mengurangi hutang. Sedangkan penelitian yang dilakukan oleh Darmayanti (2011), Saragih (2008), Yunita (2016) menemukan hasil yang berbeda yaitu bahwa profitabilitas berpengaruh negatif signifikan terhadap keputusan pendanaan karena semakin tinggi profitabilitas yang dihasilkan perusahaan maka keputusan pendanaan perusahaan akan semakin rendah, karena semakin tinggi laba yang diperoleh semakin kecil keinginan perusahaan untuk menggunakan hutang.

Profitabilitas berpengaruh terhadap keputusan pendanaan. Profitabilitas memiliki peran penting pada sebuah perusahaan dalam mengambil keputusan pendanaan Maka peneliti menurunkan hipotesis yang akan dibuktikan secara empiris:

\section{$H_{1}$ : Profitabilitas berpengaruh negatif terhadap keputusan pendanaan}

Pertumbuhan aktiva dapat disebut juga dengan pertumbuhan sumber ekonomi yang diharapkan memberikan manfaat usaha di kemudian hari. Aset dimasukkan dalam neraca dengan saldo normal debit. Perusahaan dengan tingkat pertumbuhan yang lebih cepat maka harus lebih mengandalkan sumber dana dari luar perusahaan. Menurut Darmayanti (2011) Pertumbuhan perusahaan menjadi salah satu tanda dalam menilai kemampuan perusahaan untuk membayar utang-utangnya dan kemudahan perusahaan untuk memperoleh pendanaan eksternal. Struktur aktiva adalah proporsi investasi perusahaan dalam bentuk aktiva tetap. 
Aktiva tetap adalah aktiva yang mempunyai umur kegunaan relatif permanen atau jangka panjang. Menurut Walmiaty ( 2008) "Struktur aktiva adalah investasi dari perusahaan dalam bentuk aktiva tetap yang dapat diukur dengan perbandingan antara aktiva tetap dan total aktiva perusahaan, struktur aktiva dapat dijadikan jaminan bagi investor agar investor tersebut percaya bahwa perusahaan dapat melunasi utangnya”.

Menurut Darmayanti (2011), Ayulestari et al., (2012), Ratnawati (2011) berpengaruh positif terhadap keputusan pendanaan. Pertumbuhan aktiva perusahaan semakin cepat dan membutuhkan dana yang besar maka akan semakin besar peluang perusahaan dalam menggunakan dana ekternal atau hutang.

Pertumbuhan aktiva berpengaruh terhadap keputusan pendanaan, karena perusahaan dengan pertumbuhan yang tinggi dapat Semakin besar asset diharapkan maka semakin besar hasil operasional yang dihasilkan oleh perusahaan semakin menambah kepercayaan pihak luar terhadap perusahaan. Maka peneliti menurunkan hipotesis yang akan dibuktikan secara empiris:

\section{$\mathrm{H}_{2}$ : Pertumbuhan Aktiva Berpengaruh Positif terhadap Keputusan Pendanaan}

Struktur aktiva adalah proporsi investasi perusahaan dalam bentuk aktiva tetap. Struktur aktiva dalam pecking order theory memiliki hubungan yang positif dengan keputusan pendanaan.Pada perusahaan sebagian besar dari modalnya tertanam dalam aktiva tetap,yang mengutamakan dari pendanaan internal (modal sendiri), sedangkan pendanaan eksternal (utang) hanya sebagai pelengkap.sementara itu,perusahaan yang sebagian besar dari aktivanya adahlah aktiva lancar akan mengutamakan pemenuhan kebutuhan dananya melalui utang jangka pendek.

Saragih (2008), Irmawati (2011) menyatakan struktur aktiva berpengaruh Positif terhadap keputusan pendanaan Memiliki arti bahwa semakin besar proporsi aktiva tetap yang dimiliki perusahaan maka semakin besar keputusan pendanaannya karena aktiva tetap yang dimiliki perusahaan dapat dijadikan jaminan untuk memperoleh hutang.

Struktur aktiva berpengaruh terhadap keputusan pendanaan Apabila semakin besar struktur aktiva yang dimiliki perusahaan, maka semakin besar juga peluang perusahaan menggunakan hutang. Maka peneliti menurunkan hipotesis yang akan dibuktikan secara empiris:

\section{$\mathrm{H}_{3}$ :Struktur Aktiva berpengaruh positif terhadap keputusan Pendanaan}

\section{METODE PENELITIAN}

Penelitian ini dilakukan pada PT bank permata tbk pada bulan maret 2015 sampai november 2017 . Objek merupakan apa yang hendak diselidiki di dalam kegiatan penelitian. Ada beberapa persoalan yang perlu untuk kita pahami supaya dapat menentukan serta menyusun objek penelitian di dalam metode penelitian dengan baik yaitu berhubungan dengan apa itu objek penelitian di dalam penelitian kualitatif. Objek penelitian ini adalah pada bank permata.

Jenis data didalam penelitian ini adalah time series.Time series(runtut waktu) adalah data terdiri atas satu objek yang meliputi beberapa periode waktu. Periode waktu yang dilakukan pada penelitian ini dari tahun 2015 sampai tahun 2017, yang diperoleh dari laporan keuangan PT.Bank permata Padang. Pengukuran yang digunakan dalam time series adalah data rasio. Dimana data rasio merupakan merupakan data tentang keterangan yang memberikan nilai yang diukur dari nilai absolut. Data yang dikumpulkan laporan keuangan bulan maret 2015 sam[pai November 2017. 
Tabel 1

Definisi Operasional dan Pengukuran

\begin{tabular}{|c|c|c|c|}
\hline No & Variabel & Pengertian & Rumus \\
\hline 1 & $\begin{array}{l}\text { Keputusan } \\
\text { Pendanaan }\end{array}$ & $\begin{array}{l}\text { Keputusan } \\
\text { Perusahaan Pendanaan } \\
\text { Tentang Bentuk Dan Komposisi } \\
\text { Pendanaan Yang Akan } \\
\text { Digunakan Oleh Perusahaan. } \\
\text { Mulviawan (2011) }\end{array}$ & Debt Equity Ratio $=\frac{\text { Total Hutang }}{\text { Modal Equitas }} X 10$ \\
\hline 2 & Profitabilitas & $\begin{array}{l}\text { Kemampuan perusahaan dalam } \\
\text { memperoleh laba selama periode } \\
\text { tertentu dan juga memberikan } \\
\text { gambaran tentang tingkat } \\
\text { efektifitas manajemen dalam } \\
\text { melaksanakan kegiatan } \\
\text { operasinya Irmawati (2008) }\end{array}$ & Return on Assets $=\frac{\text { Laba Bersih }}{\text { Total Assets }} \times 10$ \\
\hline 3 & $\begin{array}{l}\text { Pertumbuhan } \\
\text { Aktiva }\end{array}$ & $\begin{array}{l}\text { Aktiva Yang Digunakan Untuk } \\
\text { Aktivitas } \\
\text { Perusahaan } \\
\text { Saragih (2008) }\end{array}$ & $\begin{array}{l}\text { Pertumbuhan Aktiva } \\
\begin{array}{l}\text { Dengan Menggunakan } \\
\text { Pertumbuhan (Growth) }\end{array} \\
\text { Rumus } \\
\text { GROWTH }=\frac{\text { Tat }- \text { Tat }-1}{\text { Tat }-1} \times 100 \% \\
\text { GROWTH) = Tat -Tat }-1 \text { / Ta T-1 } \\
\text { X } 100 \% \\
\text { Keterangan: } \\
\text { Tat : Total Aktiva Tahun Berjalan } \\
\text { Tat -1 : Total Aktiva Tahun } \\
\text { Sebelumnya }\end{array}$ \\
\hline 4 & $\begin{array}{l}\text { Struktur } \\
\text { Aktiva }\end{array}$ & $\begin{array}{l}\text { Struktur Aktiva Merupakan } \\
\text { Masalah Penting Bagi Setiap } \\
\text { Perusahaan, Karena Baik } \\
\text { Buruknya Struktur Aktiva Akan } \\
\text { Mempunyai Efek Yang } \\
\text { Langsung Terhadap Posisi } \\
\text { Finansial Perusahaan. } \\
\text { Ratnawati (2011) }\end{array}$ & $\begin{array}{l}\text { Struktur aktiva dapat diukur dengan } \\
\text { StrukturAkiva }=\frac{\text { Aktiva Tetap }}{\text { Total Aktiva }} \times 100 \%\end{array}$ \\
\hline
\end{tabular}

\section{Teknik Analisis Data}

Tahapan dalam pengelolaan data dalam penelitian menggunakan bantuan program SPSS. Model penelitian yang digunakan analisis Model regrersi Berganda dimana mengetahui pengaruh profitabilitas, pertumbuhan aktiva dan struktur aktiva terhadap keputusan pendanaan

$$
\mathrm{Y}=\mathrm{a}_{+} \beta_{1} \mathrm{X}_{1}+\beta_{2} \mathrm{X}_{2}+_{+} \beta_{3} \mathrm{X}_{3}+\mathrm{e}
$$

Berdasarkan model regresi berganda menjelaskan bahwa $\mathrm{Y}$ adalah Keputusan Pendanaan, X1 merupakan Profitabilitas, X2 merupakan Pertumbuhan Aktiva, dan X3 merupakan Struktur aktiva, a merupakan konstanta, $\beta 1$ - $\beta 4$ merupakan koefisien regresi dan terakhir e merupakan error. 


\section{Pengujian Hipotesis}

Uji $R^{2}$ adalah perbandingan anatar variasi Y yang dijelaskan oleh X1dan X2 secara bersama dibandingkan dengan variasi total Y.Apabila analisis yang digunakan adalah regresi sederhana, maka yang digunakan adalah nilai $\mathrm{R}$ Square. Namun, apabila analisis yang digunakan adalah regresi bergenda, maka yang digunakan adalah Adjusted $R$ Square .Untuk mengukur besarnya sumbangan variabel $\mathrm{X} 1$ dan $\mathrm{X} 2$ terhadap variasi (naik turunnya) $\mathrm{Y}$ digunakan Goodness of Fit R-Square (R2). R2 ini juga disebut dengan koefisien determinasi, dan nilainya berkisaran antara 0 sampai $1\left(0<\mathrm{R}^{2}<1\right)$ semakin mendekati 1 berarti semakin tepat garis regresi untuk meramalkan nilai variabel terkait Y. (Sujarweni, 2016)

Uji T menunjukkan seberapa jauh pengaruh satu variabel bebas secara individual dalam menerangkan variasi variabel terikat Pengambilan keputusan uji hipotesis secara parsial juga didasarkan pada nilai probabilitas yang didapatkan dari hasil pengolahan data melalui program SPSS Statistik Parametrik sebagai berikut: a) Jika nilai signifikan diuji $t>$ 0,05 maka pelaporan dan pengukuran biaya kualitas terhadap penjualan, b) Jika signifikan diuji $\mathrm{t}<0,05$ maka pelaporan dan pengukuran biaya kualitas terhadap penjualan.

\section{HASIL DAN PEMBAHASAN \\ Koefisien Determinan (R-Squere)}

Tabel 2

Koefisien Determinan

\begin{tabular}{|l|l|}
\hline Keterangan & Koefisien \\
\hline R-Squere & $\mathbf{0 , 5 3 6}$ \\
\hline Adjusted $R$-Squere & $\mathbf{0 , 4 8 8}$ \\
\hline
\end{tabular}

Berdasarkan tabel 2 dapat dijelaskan bahwa nilai adjusted $R$ square adalah sebesar 0,488 . Artinya kemampuan variabel independen yang terdiri dari profitabilitas , pertumbuhan aktiva dan struktur aktiva dalam menerangkan variabel dependen yang terdiri dari keputusan pendanaan adalah sebesar 48,80\%, sedangkan sisanya sebesar 51,20\% dipengaruhi oleh variabel lain selain dari variabel yang diteliti dalam penelitian ini.

\section{Pengujian Hipotesis}

Tabel 3

\section{Pengujian Hipotesis}

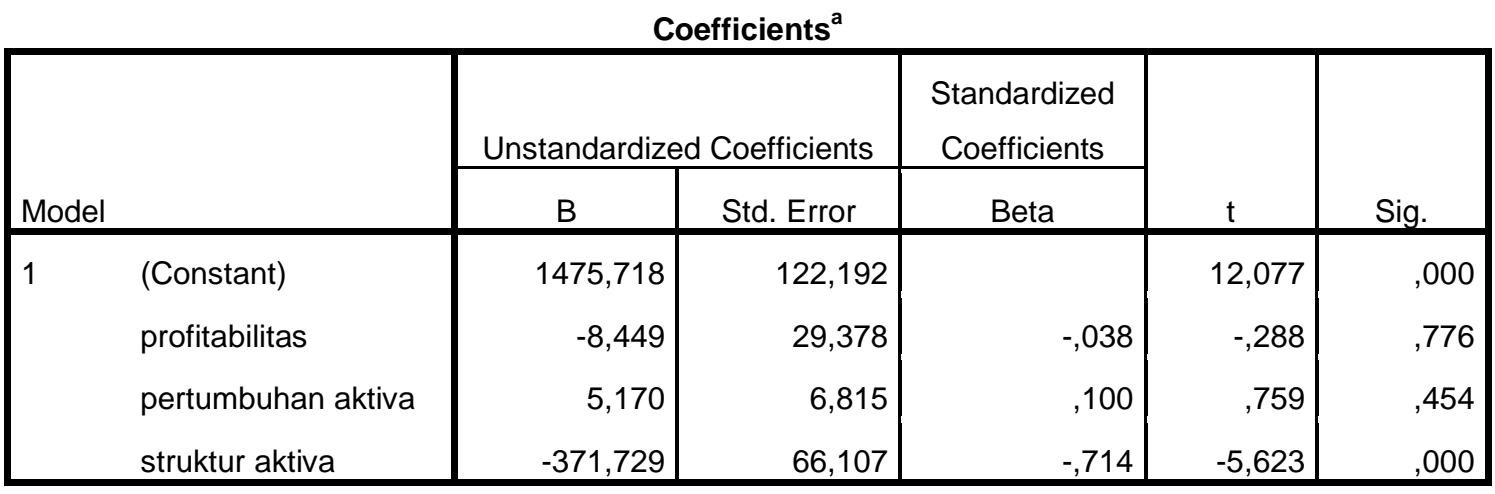

a. Dependent Variable: Keputusan pendanaan

Berdasarkan hasil pengujian hipotesis pertama menunjukkan bahwa profitabilitas mempunyai niai sig 0,776, dengan menggunakan tingkat kesalahan sebesar 0,05. Hasil yang 
diperoleh menunjukkan bahwa 0,776>0,05 maka keputusan adalah H0 Diterima dan Ha ditolak, maka keputusannya bahwa profitabilitas tidak mempunyai pengaruh terhadap keputusan pendanaan

Berdasarkan hasil pengujian hipotesis kedua menunjukkan bahwa pertumbuhan aktiva mempunyai niai sig 0,454, dengan menggunakan tingkat kesalahan sebesar 0,05. Hasil yang diperoleh menunjukkan bahwa 0,454>0,05 maka keputusan adalah H0 Diterima dan Ha ditolak, maka keputusannya bahwa pertumbuhan tidak mempunyai pengaruh terhadap keputusan pendanaan

Berdasarkan hasil pengujian hipotesis ketiga menunjukkan bahwa struktur aktiva mempunyai niai sig 0,00, dengan menggunakan tingkat kesalahan sebesar 0,05. Hasil yang diperoleh menunjukkan bahwa 0,454>0,05 maka keputusan adalah H0 Ditolak dan Ha diterima, maka keputusannya bahwa struktur aktiva mempunyai pengaruh terhadap keputusan pendanaan.

\section{Pembahasan}

\section{Pengaruh Profitabilitas Terhadap Keputusan Pendanaan}

Hasil penelitian yang telah dilakukan dapat diinterpretasikan bahwa profitabilitas tidak mempengaruhi keputusan pendanaan. Tinggi atau rendahnya profitabilitas pada bank permata cabang padang tidak mempengaruhi keputusan pendanaan yang dilakukan oleh manager. Laba PT Bank Permata selama bulan maret 2015 sampai november 2017 mengalami berfluktasi sehingga manager dalam melakukan investasi dan melakukan pembiayaan untuk kegiatan operasional perusahaan tidak mempengaruhi keputusan pendanaan yang dilakukannya. Profitabilitas PT Bank Permata yang seharusnya dapat menjadi bahan pertimbangan manager dalam membuat keputusan pendanaan dalam menggunakan dana external dan internal yang dapat digunakan untuk kegiatan operasional perusahaan dan investasi. Semakin besar laba perusahaan maka perusahaan dapat menekan hutang perusahaan sehingga dapat mempengaruhi keputusan pendanaan.

\section{Pengaruh Pertumbuhan Aktiva, Terhadap Keputusan Pendanaan}

Hasil penelitian yang dilakukan dapat diinterpretasikan bahwa rebdah atau tingginya pertumbuhan aktiva PT Bank Permata Cabang Padang tidak mempengaruhi terhadap meningkatnya keputusan pendanaannya. Hal ini terjadi bahwa tidak ada mempengaruhi terhadap keputusan pendanaan yang telah dilakukan manager terhadap perusahaan. Hal disebabkan bahwa kondisi keuangan perusahaan yang tidak stabil sehingga manager melakukan alternatif yang lain sebagai sumber pendanaan, seperti yang dilakukan manager PT Bank Permata menjual kredit bermasalah alias non performing loan (NPL) sebesar Rp 1 triliun sampai Rp 1,5 triliun. Salah satu aset yang dijual adalah kredit bermasalah ke PT Garasindo senilai Rp 1,2 Triliun. Hasil penjualannya yang dilakukan dapat memberikan keuntungan laba kepada perusahaan. Perusahaan tidak perlu melakukan pinjaman utang kepada pihak ketiga.

\section{Pengaruh Struktur Aktiva Terhadap Keputusan Pendanaan}

Hasil penelitian yang telah dilakukan dapat diinterpretasikan bahwa struktur aktiva berpengaruh negatif terhadap keputusan pendanaan .Pada PT Bank Permata Manajemen menggunakan posisi asset tetap sebagai dasar dalam pengambilan hutang. Hal ini terkait dengan kecendrungan bahwa manajemen akan berhati-hati dalam menggunakan dan membuat kebijakan utang baru, agar kewajiban perusahaan akan semakin kecil. Semakin tinggi struktur aktiva (semakin besar jumlah aktiva tetap) maka penggunaan modal sendiri akan semakin tinggi, dan penggunaan modal asing akan semakin sedikit atau keputusan pendanaan semakin rendah. Penggunaan aset PT Bank Permata Cabang Padang 
menggunakan aset perusahaan untuk mengurang pengambilan keputusan dalam melakukan pinjaman perusahaan. Aset yang lebih banyak lebih efisien memanfaatkan aset perusahaan dalam kegiatan operasional perusahaan. Perusahaan yang memerlukan dana perusahaan memanfaatkan aset untuk dijual.

\section{KESIMPULAN}

Berdasarkan hasil dapat disimpulkan bahwa 1) profitabilitas tidak berpengaruh terhadap keputusan pendanaan 2) Pertumbuhan aktiva tidak berpengaruh terhadap keputusan pendanaan, 3) Struktur berpengaruh negatif terhadap keputusan pendanaan .

\section{DAFTAR PUSTAKA}

Ayulestari, P., Kirmizi, \& A, A. A. (2012). Analisis Pengaruh Pertumbuhan Asset, Profitabilitas, Pertumbuhan Penjualan Dan Kebijakan Dividen Terhadap Keputusan Pendanaan Pada Perusahaan Manufaktur Yang Terdaftar Di Bursa Efek Indonesia. Jurnal Ekonomi, 1-14.

Brigham, E. F., \& Gepenski, L. C. (2008). Financial Manajemen Theory and Practice (10th ed.). Harcourt College.

Darmayanti, N. P. M. (2011). Pengaruh profitabilitas, pertumbuhan aktiva, dan struktur aktiva terhadap keputusan pendanaan pada perusahaan. Jurnal nEkonomi Universitas Udayana, 714-730.

Irmawati, R. (2008). Pengaruh profitabilitas pertumbuhan aset dan likuidasi terhadap keputusan pendanaan.

Irmawati, R. (2011). Pengaruh Profitabilitas Pertumbuhan aktiva dan Struktur aktiva Terhadap Keputusan Pendanaan. Jurnal Ekonomi, 1-18.

Keown, A. J., \& Martin, J. D. (2011). Manajemen Keuangan: Prinsip dan Penerapan. (Kesepuluh). Jakarta: PT. Indeks.

Mulviawan, Y. (2011). Pengaruh Profitabilitas, Pertumbuhan Aset dan Ukuran Perusahaan Terhadap Debt To Equity Ratio Pada Perusahaan Realestate dan Property di BEI Tahun 2005-2011. Journal of Finance.

Mulyadi. (2002). Akuntansi Manajemen: Konsep, Manfaat, \& Rekayasa (ed. 3).

Ratnawati, T. (2011). Pengaruh Langsung dan Tidak Langsung Faktor Ekstern , Kesempatan Investasi dan Pertumbuhan Assets Terhadap Keputusan Pendanaan Perusahaan yang Terdaftar Pada Bursa Efek Jakarta ( Studi pada Industri Manufaktur Masa Sebelum Krisis dan Saat Krisis ). Jurusan Ekonomi Akuntansi, Fakultas Ekonomi - Universitas Kristen Petra, 65-75.

Rivandi, M., Saleh, S. M., \& Septiano, R. (2017). Leverage, Profitabilitas, Ukuran Perusahaan, Pengungkapan Corporate Social Responsibility dengan Pendekatan Kausalitas. Jurnal Pundi, Vol. 01(No. 01), 11-22.

Saragih, J. L. (2008). Pengaruh Profitabilitas Pertumbuhan aktiva dan Struktur aktiva terhadap keputusan pendanaan. Jurnal Ekonomi, 85-93.

Sartono. (2001). definisi profitabilitas. Jakarta.

Sudana, I. M. (2011). Manajemen Keuangan Perusahaan: Teori dan Praktik. Jakarta: Erlangga.

Walmiaty, M. (2008). Rina Walmiaty Mardi : Pengaruh Struktur Aktiva, Profitabilitas Dan Kebijakan Dividen Terhadap Struktur..., 2008 USU e-Repository @ 2008.

Yunita. (2016). Pengaruh Profitabilitas , Pertumbuhan Asset Dan Struktur Aktiva Terhadap Keputusan Pendanaan Pada Perusahaan Manufaktur. Jurnal Ekonomi. 